\title{
Monitoring Evoked Potentials in Order to Guarantee Integrity During Spine Surgery
}

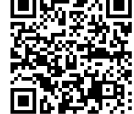

Diego Liberati*

National Research Council of Italy, Italy

Submission: June 27, 2018; Published: July 12, 2018

*Corresponding author: Diego Liberati, National Research Council of Italy, Italy, Email: diego.liberati@gmail.com

\section{Opinion}

As early as in 1986 during my first visiting scholarship in New York University thanks to a NATO grant, together with E.R. John, then director of the Brain Research Labs, we were monitoring via Evoked Potentials the integrity of the facial nerve of people undertaking fossa tumor surgery in order to early detect heating of the facial due to laser surgery in the close cavity and thus stop for a while the surgeon in order to prevent face deformation after surgery, the main uncomfortable drawback of such surgery. My contribution was to develop and apply my single-sweep Autoregressive analysis [1-5] to make detection as early as one second delay instead of more than a minute needed with conventional averaging.

The approach enjoyed quite a success: did present its refinement to a conference in New Orleans in October 1988 [6], where the chief scientist of the local Naval Research Lab invited me to visit their simulation of pilot ejection where the need was to provide enough energy to rescue the pilot from the falling jet but not too much in order not to destroy his spine at neck: simulations, done with a real marine, were astonishing, slow movie showed the head almost touching knees like in a cartoon at the ejection, being the marine sit tight to the accelerated chair The application of the same approach with one of his pupil, Dr

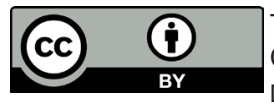

This work is licensed under Creative Commons Attribution 4.0 License DOI: 10.19080/JHNSS.2018.03.555605
Berenice Kaufman, and a few of bright student of mines was also quite satisfactory [7].

The further step is thus the application to spine surgery: some experiments have been done, stimulating somatosensory on feet, integrity of the spine can be monitored second by second through single sweep analyst of the somatosensory evoked potential, thus avoiding for instance obnoxious hyper distraction during the surgery.

\section{References}

1. (1987) Proc IEEEI-EMBS IX Annual Conf. Boston MA, USA.

2. (1987) Proc VI1 Nordic Meet. Med Biol Eng, Trondheim, Europe.

3. (1987) Electroencephalography and clinical neurophysiology Supplement 40: 8-12.

4. Cerutti S, Chiarenza G, Liberati D, Mascellani P, Pavesi G (1988) A parametric method of identification of single-trial event-related potentials in the brain IEEE transactions on Biomedical Engineering 35(9): 701-711.

5. Liberati D, Cerutti S, Di Ponzio E, Ventimiglia V, Zaninelli L (1989) The implementation of an autoregressive model with exogenous input in a single sweep visual evoked potential analysis. J Biomed Eng 11(4): 285-292.

6. (1988) X IEEE EMBS: 976-977, New Orleans, Louisiana, USA.

7. (1992) XIV IEEE-EMBS:2454-2455, Paris, UK.

Your next submission with Juniper Publishers
will reach you the below assets
- Quality Editorial service
- Swift Peer Review
- Reprints availability
- E-prints Service
- Manuscript Podcast for convenient understanding
- Global attainment for your research
- Manuscript accessibility in different formats
( Pdf, E-pub, Full Text, Audio)
- Unceasing customer service
Track the below URL for one-step submission
https://juniperpublishers.com/online-submission.php

